\title{
Present status of micro- and polycrystalline silicon solar cells made by hot-wire chemical vapor deposition
}

\author{
Ruud E.I. Schropp* \\ Utrecht University, Debye Institute, SID - Physics of Devices, P.O. Box 80000, 3508 TA Utrecht, The Netherlands
}

\begin{abstract}
Considerable effort is presently put into the development of thin film microcrystalline silicon, because it has a larger longwavelength response than amorphous silicon, while at the same time it is essentially stable. In this review, the latest achievements in this field as obtained by hot-wire chemical vapor deposition (HWCVD) technology are presented and illustrated by the performance of silicon thin film devices. Since microcrystalline silicon has an indirect band gap, the absorption coefficient is low. Nevertheless, using light trapping geometries, the required thickness can be kept below $2 \mu \mathrm{m}$. In spite of this small thickness long deposition times are still required and therefore the achievement of higher deposition rates is important for production. Alternatively, multijunction cells, including amorphous components made at a higher deposition rate, can lead to lower costs while improving the overall efficiency. By doubling the catalytic surface in HWCVD, we have recently achieved a deposition rate of $7 \mathrm{~nm} / \mathrm{s}$ for polycrystalline silicon. As these layers tend to be more porous, a new optimum in the gas-phase reaction chemistry was found in a regime of reduced filament temperature and higher hydrogen dilution. This has led to polycrystalline $\mathrm{n}-\mathrm{i}-\mathrm{p}$ type cells made at more than twice the deposition rate while reproducing the cell efficiency. If the crystallinity is relaxed, allowing an increase of the amorphous volume fraction, microcrystalline silicon (rather than polycrystalline silicon) is obtained. In this mode, the layers more readily possess the compactness that is required to prevent post-oxidation. We present the world's first HWCVD multibandgap triple junction cell with an efficiency of $9.1 \%$ on plain stainless steel and show the future potential of this technology.
\end{abstract}

(C) 2003 Elsevier B.V. All rights reserved.

Keywords: Hot-wire CVD; Tandem solar cells; Thin film microcrystalline silicon; High deposition rate; Low temperature processes

\section{Introduction}

Catalytic decomposition (catalytic chemical vapor deposition (Cat-CVD); [1]) of silane or silane/hydrogen mixtures at a resistively heated filament (therefore, also called hot-wire chemical vapor deposition (HWCVD); [2]) takes place in a deposition regime that is fundamentally different from that where plasmas are involved. HWCVD is a relatively new deposition technology that has shown technological and scientific developments over the past 10 years, providing improved control of parameters. The technology is undergoing significant progress, similar to the developments that plasma enhanced CVD (PECVD) has gone through in the 1970s and 1980s. HWCVD is becoming increasingly mature [3] and presently yields devices with state-of-the-art

\footnotetext{
*Tel.: + 31-30-2533170; fax: +31-30-2543165.

E-mail address: r.e.i.schropp@phys.uu.nl (R.E.I. Schropp).
}

properties, even though our understanding of gas-phase and growth reactions is far from complete. The high deposition rate of silicon-based thin films makes this method particularly interesting for application to, among others, thin film transistors (TFTs) and low-cost photovoltaic devices (solar cells). In the latter application, hot-wire deposited layers can be found as active materials (thin film absorbers), but also as passivation layers and antireflection layers $\left(\mathrm{SiN}_{x}: \mathrm{H}\right)$.

The high efficiency of $\mathrm{H}_{2}$ dissociation at a tungsten wire has been utilized since the 1960s [4]. The first patent [5] and publication [6] on CVD appeared in 1979 ('thermal CVD') in the USA. Approximately 6 years later, Matsumura and Tachibana [7] used this technique for the preparation of fluorinated amorphous silicon. The preparation of hydrogenated amorphous silicon (a$\mathrm{Si}: \mathrm{H})$ was further investigated by Doyle et al. [8] and Matsumura $[1,9,10]$ in the late 1980 s, showing the high deposition rate as the prominent feature. Renewed inter- 
est in the deposition method came in 1991 due to Mahan et al. [2,11], who demonstrated for the first time the possibility to produce device-quality a-Si:H with a hydrogen concentration below 1 at. $\%$. Due to this development, many laboratories entered the field and presently, well over 30 laboratories have HWCVD deposition facilities. The first thin film silicon solar cells were made in 1993 at the University of Kaiserslautern and NREL, while the first TFTs were made in 1995 at Utrecht University and JAIST. Within Europe, more than 10 groups are using the technology to create novel thin films and devices. In Japan, a new NEDO project has started recently, aiming at $13 \%$ efficient thin film Si solar cells. The main partners are JAIST, Osaka University and Gifu University.

The technology has yielded silicon thin films with amorphous, micro- and polycrystalline properties $[12,13]$. Doped layers, both p-type and n-type, have been shown to be feasible. Alloys, such as a-SiGe:H and $\mathrm{a}-\mathrm{SiC}: \mathrm{H}$ have been demonstrated. Dielectric layers, such as silicon nitride with device quality properties are available. Even $\mathrm{SiO}_{2}$ layers have been made with the HWCVD technique. The technology for large area deposition, even in excess of $1.5 \mathrm{~m}$ wide, has been demonstrated recently.

\section{HWCVD process}

In the HWCVD process the feedstock gases are very efficiently cracked into atomic radicals at the surface of a hot filament (usually tungsten or tantalum), which is held at a temperature higher than $1500{ }^{\circ} \mathrm{C}$. It can be calculated that during the residence time of the silane gas, each molecule collides with the filament surface more than 10 times. This leads to very efficient radical production compared to PECVD, since the first collision normally already atomizes the molecule, while in PECVD the decomposition relies on electron impact with the molecule in a $3 \mathrm{D}$ space. In contrast to the conventional PECVD technique, no ions are created. The hot filament emits a considerable electron current, but the energy of these electrons is too low to cause impact ionization. The reactive species are subsequently transported to the substrate in a low pressure ambient (typically only $20 \mu$ bar for amorphous silicon). This enables a high deposition rate without gas-phase particle formation. Recently, it has been shown that ultrahigh deposition rates can be achieved (more than 100 times faster than PECVD [14]). These rates are achieved with two tungsten filaments located at $3.2 \mathrm{~cm}$ from the substrate. The saturated defect density of the a-Si:H is typically (2-4) $\times 10^{16} / \mathrm{cm}^{3}$ and independent of the deposition rate, up to $130 \AA / \mathrm{s}$, though the void density increases by a factor $\sim 100$ [15]. Solar cells made on stainless steel (SS) with these films up to a deposition rate of $50 \AA / s$ have initial and stabilized efficiencies similar to cells made at low rate, of 5.7 and $4.8 \%$, respectively.

The most frequently used filament materials are tungsten (W) and tantalum (Ta). Matsumura [10] reported on molybdenum (Mo), vanadium (V) and platinum (Pt) as filament materials. More recently, Duan et al. [16] and van Veenendaal et al. [17] used rhenium (Re) as the filament material. Van Veenendaal et al. showed that, except for the highest filament temperature $T_{\text {fil }}>$ $1950{ }^{\circ} \mathrm{C}$, polycrystalline silicon can be deposited with crystal orientation exclusively in the (2 20) direction. Morrison and Madan [18] reported on the deposition of microcrystalline silicon using graphite $(\mathrm{C})$ as the catalyzer. Brühne et al. [19] also reported on the use of graphite for the deposition of microcrystalline silicon with (2 20$)$ orientation only. The deposited layers did, however, contain a considerable amount of carbon. Iridium (Ir) appears to be the most suitable filament for $\mathrm{SiO}_{2}$ deposition [3].

Using tungsten filaments at sufficiently high filament temperature, silane is fully cracked into one $\mathrm{Si}$ and four $\mathrm{H}$ atoms. Only at temperatures below $1430{ }^{\circ} \mathrm{C}, \mathrm{SiH}_{2}$ and $\mathrm{SiH}_{3}$ could be detected [20]. It is suggested that in this temperature regime, a $\mathrm{Si} / \mathrm{W}$ alloy is formed on the filament [21]. From further experiments, we deduced that this alloy affects the decomposition of silane at the filament surface and virtually blocks the decomposition of $\mathrm{H}_{2}$ [22]. Matsumura [23] also found that at filament temperatures above $1430{ }^{\circ} \mathrm{C}$, for $\mathrm{W}$, Mo and Ta filaments, the major species desorbed from the filament is the $\mathrm{Si}$ atom. The maximum production of $\mathrm{Si}$ atoms is observed at approximately $1530{ }^{\circ} \mathrm{C}$. The temperature dependence below $T_{\text {fil }}=1430{ }^{\circ} \mathrm{C}$ is large and different for these three filaments. Activation energies for $\mathrm{Si}$ atom desorption from the filament are found to be $(251 \pm 63)$, $(96 \pm 25)$ and $(71 \pm 20) \mathrm{kJ} / \mathrm{mol}$ for Mo, Ta and $\mathrm{W}$ filaments, respectively [20]. The energy needed for $\mathrm{Si}$ atom production is much lower than 4 times the $\mathrm{Si}-\mathrm{H}$ bond dissociation energy of $300 \mathrm{~kJ} / \mathrm{mol}$. Both the large differences for the different filaments and the small values of the activation energies indicate that the decomposition of $\mathrm{SiH}_{4}$ on the hot filament is caused by catalytic reactions at the filament surface.

At low pressures $(<5 \mu$ bar $)$, the $\mathrm{Si}$ and $\mathrm{H}$ atoms that come from the filament thermally diffuse to the substrate [24] with only few or no gas-phase reactions. Duan et al. [25] reported on single photon ionization mass spectrometry measurements at $1.8 \times 10^{-2} \mu$ bar at $\mathrm{W}$ filament temperatures of $1950{ }^{\circ} \mathrm{C}$. The major silicon containing gas species detected is elemental $\mathrm{Si}$ itself, along with minor contributions of $\mathrm{SiH}_{3}$ and $\mathrm{Si}_{2} \mathrm{H}_{x}$. However, the pressures used in this study are more than an order of magnitude lower than the pressures used during practical silicon deposition (the pressure used during deposition is in the order of 0.1 and 0.02 mbar 
for microcrystalline and amorphous silicon, respectively).

At higher pressures ( $>5 \mu \mathrm{bar}$ ), the silicon atom is highly reactive. It can abstract an $\mathrm{H}$ atom from silane, resulting in $\mathrm{SiH}$ and $\mathrm{SiH}_{3}$, or it can insert into a $\mathrm{Si}-\mathrm{H}$ bond [26]. Among the reaction products, $\mathrm{HSiSiH}_{3}$ is formed through an exothermic reaction and will thus be the most probable species to be formed. The formation reaction of $\mathrm{HSiSiH}_{3}$ has been studied by ab initio molecular orbital calculations by Sakai et al. [27]. According to these calculations, $\mathrm{HSiSiH}_{3}$ is unstable and will react with $\mathrm{SiH}_{4}$ in the gas-phase. One of the reaction products, $\mathrm{H}_{2} \mathrm{SiSiH}_{2}$, is a rather stable closedshell molecule and it has been expected to be an important precursor species for the film growth. Inoue et al. [20] suggested that another reaction product, $\mathrm{SiH}_{2}$, further reacts with $\mathrm{SiH}_{4}$ to yield $\mathrm{Si}_{2} \mathrm{H}_{6}$. In their experiments indeed the most prominent species detected is $\mathrm{Si}_{2} \mathrm{H}_{6}$.

Atomic hydrogen, which is abundantly present in the reactor, results in the reaction $\mathrm{H}_{2}+\mathrm{SiH}_{4} \rightarrow \mathrm{SiH}_{3}+\mathrm{H}_{2}$. The $\mathrm{SiH}_{3}$ species does not react with $\mathrm{SiH}_{4}$ and the only gas-phase reaction of $\mathrm{SiH}_{3}$ is self-recombination.

Gallagher also proposed a gas-phase growth reaction, in which Si atoms react with silane [28], and subsequent reactions lead to more stable silanes such as $\mathrm{Si}_{2} \mathrm{H}_{6}$ and $\mathrm{Si}_{3} \mathrm{H}_{6}$. Goodwin [29] pointed out, that the reaction yielding $\mathrm{Si}_{2} \mathrm{H}_{2}+\mathrm{H}_{2}$ is energetically favored, since it is an exothermic one by $110 \mathrm{~kJ} / \mathrm{mol}$. The relative contribution of $\mathrm{Si}_{2} \mathrm{H}_{2}$, being a closed-shell molecule, to film growth is, however, still very uncertain as the reaction probability is unknown. This disilyne radical may, however, possess a surface mobility similar to $\mathrm{SiH}_{3}$ and may thus contribute to the growth of more dense films.

In summary, the main gas-phase reaction species are thus: $\mathrm{SiH}_{3}, \mathrm{Si}_{2} \mathrm{H}_{6}, \mathrm{Si}_{3} \mathrm{H}_{6}$ and $\mathrm{H}_{2} \mathrm{SiSiH}_{2}$. It is expected that the detection of the actual gas-phase reaction species will provide further insight.

\section{Main differences between PECVD and HWCVD}

Whereas PECVD is presently the workhorse of the semiconductor industry, it has a number of limitations. First, the primary concern is the low deposition rate, in particular for $\mu \mathrm{c}-\mathrm{Si}: \mathrm{H}$ (indirect-gap) intrinsic layers. Attempts to achieve higher deposition rates have usually led to films with lower density (less compact) and higher void content. Although the application of the PECVD technique in the very high frequency (VHF) domain (VHF-CVD) and/or the high pressure domain leads to higher deposition rates, it has been difficult to scale up the VHF technique to very large area $\left(>1 \mathrm{~m}^{2}\right)$, due to the finite wavelength of the radio frequency excitation and difficulties at substrate edges due to plasma confinement. Moreover, high power VHF generators are less standard than the $13.56 \mathrm{MHz}$ generators, and therefore still more expensive, whereas the highpressure regime at $13.56 \mathrm{MHz}$ may suffer from nonuniformity upon scaling up.

The absence of any kind of plasma in HWCVD has three important advantages.

(1) The first advantage is that HWCVD is inherently free of dust. Since there is no plasma, the most important source of microparticles that is present in conventional PECVD is eliminated. Plasmas are a source of dust since the positive potential in the bulk of the plasma tends to trap negatively charged particles that are likely to grow, leading to inferior films. To avoid dust in conventional production systems, e.g. in the TFT liquid crystal display (LCD) business or in the thin film a-Si/ a-SiGe tandem solar cell business, depletion of silane must be avoided. This leads to very low source gas utilization rates in practice. In the case of TFT production, gas utilization is even as low as 1\%. HWCVD offers the possibility to almost completely deplete the source gases, and thus, gas utilization efficiencies of up to $80 \%$ have been reported for a-Si:H deposition [30].

(2) The second advantage is that no ions are involved and that damage due to energetic ions does not occur. This is particularly useful for passivation layers on electronic structures.

(3) The third advantage is that the substrate is not part of the deposition mechanism itself (similar to remote PECVD techniques), which facilitates good uniformity on a wider selection of substrate types (insulating, conducting). In HWCVD, transport mechanisms for moving the individual substrate panels or a continuous web through the deposition zones can be designed and constructed independently of the deposition mechanism.

In addition to the high deposition rate and high gas utilization, the elimination of expensive r.f. power supplies and matching boxes makes the HWCVD technique a low-cost production method for silicon thin films. For this technique to become more widely adopted, it is important to physically demonstrate the large area capabilities of the technique. With a special new design for a hot-wire assembly with a showerhead [30], Anelva has demonstrated a thickness uniformity of $\pm 7.5 \%$ over $96 \times 40 \mathrm{~cm}^{2}$ substrate area, and has thus overcome two main difficulties, the sagging of the filaments and the silicidation of the catalyst. A deposition system using HWCVD over even larger areas $(150 \mathrm{~cm}$ wide) was recently presented by ULVAC, using a vertical ('harplike') arrangement, thus considerably reducing the footprint.

\section{Recent results obtained at Utrecht University}

Our equipment consists of two HWCVD chambers (Fig. 1) that are connected to a multichamber ultrahigh vacuum (UHV) system that has an additional three PECVD chambers. In addition, our laboratory has anoth- 


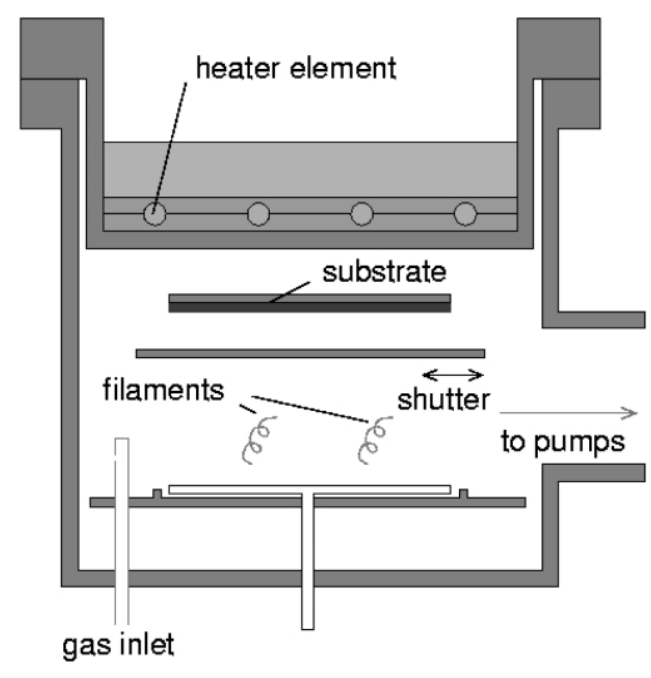

Fig. 1. Schematic cross-section of a hot-wire deposition chamber at Utrecht University. It basically contains a substrate holder, a shutter, a hot-wire assembly, a gas inlet and a pump port. The substrate holder is optionally heated using the external heater. One or multiple filaments are located at $3-8 \mathrm{~cm}$ from the substrate.

er multichamber UHV system where the plasma- and HW-assemblies can easily be exchanged. This arrangement offers the opportunity to create different geometries and deposition parameters that are optimized for each type of intrinsic layer (amorphous/microcrystalline or polycrystalline). Tungsten filaments are used for poly$\mathrm{Si}: \mathrm{H}$, tantalum filaments for a-Si:H and $\mu \mathrm{c}-\mathrm{Si}: \mathrm{H}$. Polysilicon is obtained at substrate temperatures between 430 and $530{ }^{\circ} \mathrm{C}$. Amorphous and microcrystalline silicon films are obtained between 220 and $430{ }^{\circ} \mathrm{C}$. All intrinsic layers are incorporated in devices using plasma-deposited p-type and n-type layers, though presently n-type $\mu \mathrm{c}-\mathrm{Si}: \mathrm{H}$ by HWCVD is also available.

The gas flow in the HWCVD chambers is perpendicular to the length of the wires. The temperature of the wires is typically $1800-2000{ }^{\circ} \mathrm{C}$, while for poly-Si:H deposition it is deliberately reduced to $1750-1850{ }^{\circ} \mathrm{C}$ [22]. With the help of a heat transport model [31] the substrate temperature has been carefully calibrated. The substrate loading system is equipped with a shutter, which hermetically shields the substrate from any deposition during preheating.

At Utrecht University, the main focus in HWCVD is on the deposition of a-Si:H [32], micro- and poly-Si:H $[33,34]$ and $\operatorname{SiN}_{x}[35]$. Here we discuss the latest results on amorphous, micro- and poly-Si:H.

Microcrystalline silicon ( $\mu \mathrm{c}-\mathrm{Si}: \mathrm{H})$ and polycrystalline silicon (poly-Si:H) are attractive alternatives for aSiGe:H as the low-bandgap absorbing component in tandem cells and triple cells. Although a-SiGe:H has a large absorption coefficient for light at a long-wavelength, its drawback is that materials with a band gap smaller than $1.4 \mathrm{eV}$ are defect-rich and must be made under high hydrogen-dilution conditions in order to be stable, thus leading to very low deposition rates $(\approx 1$ $\AA / s)$. Therefore, a large research effort, nowadays, is put into the development of microcrystalline silicon, which also has a large long-wavelength response and, moreover, is essentially stable if the microcrystalline volume ratio is above a certain threshold value. Further advantages of pure silicon-hydrogen materials are: (i) a band gap lower than $1.3 \mathrm{eV}$ can be obtained without sacrificing electronic transport properties, (ii) the use of the quite expensive $\mathrm{GeH}_{4}$ is avoided and (iii) cells incorporating $\mu \mathrm{c}-\mathrm{Si}: \mathrm{H}$ do not show light-induced degradation.

\subsection{Poly-Si:H}

We have recently identified the optimum filament conditions as well as the gas flow and gas mixtures that are needed for obtaining (2 20$)$-oriented poly-Si:H. Highly oriented poly-Si has some unique properties, such as a very intrinsic nature (oxygen levels down to $3 \times 10^{18} / \mathrm{cm}^{3}$ ) and very good coalescence of the grains [36]. It has already been applied in thin poly-Si TFTs [37] and (tandem) solar cells [38].

Van der Werf et al. [39] showed in the temperature range above $1500{ }^{\circ} \mathrm{C}$ that the filament temperature decreases upon exposure of the filament to hydrogen. This decrease is explained by the power consumption needed for the dissociation of hydrogen on the filament surface. At relatively low filament temperatures, the filament is covered by a silicon-rich silicide, as reported by van Veenendaal et al. [20,40]. For tungsten filaments, an increase in silicon content was shown in the nearsurface region of a tungsten filament with time, while the silicon content on a tantalum filament shows saturation rather quickly (Fig. 2).

Using the above combined results it is suggested [21] that the degree of coverage of the filament with $\mathrm{Si}$ primarily affects the catalytic dissociation of $\mathrm{H}_{2}$ molecules and that the reduced primary dissociation of $\mathrm{H}_{2}$ in $\mathrm{SiH}_{4} / \mathrm{H}_{2}$ mixtures promotes the deposition of micro-

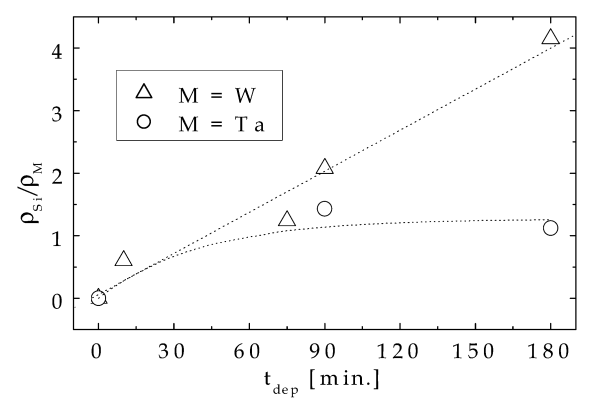

Fig. 2. Silicon content in the near-surface region of the filament $\left(\rho_{\mathrm{Si}} / \rho_{\mathrm{M}}\right)$ as a function of deposition time $\left(t_{\mathrm{dep}}\right)$, for different filament materials (M). The lines are guides to the eye. 


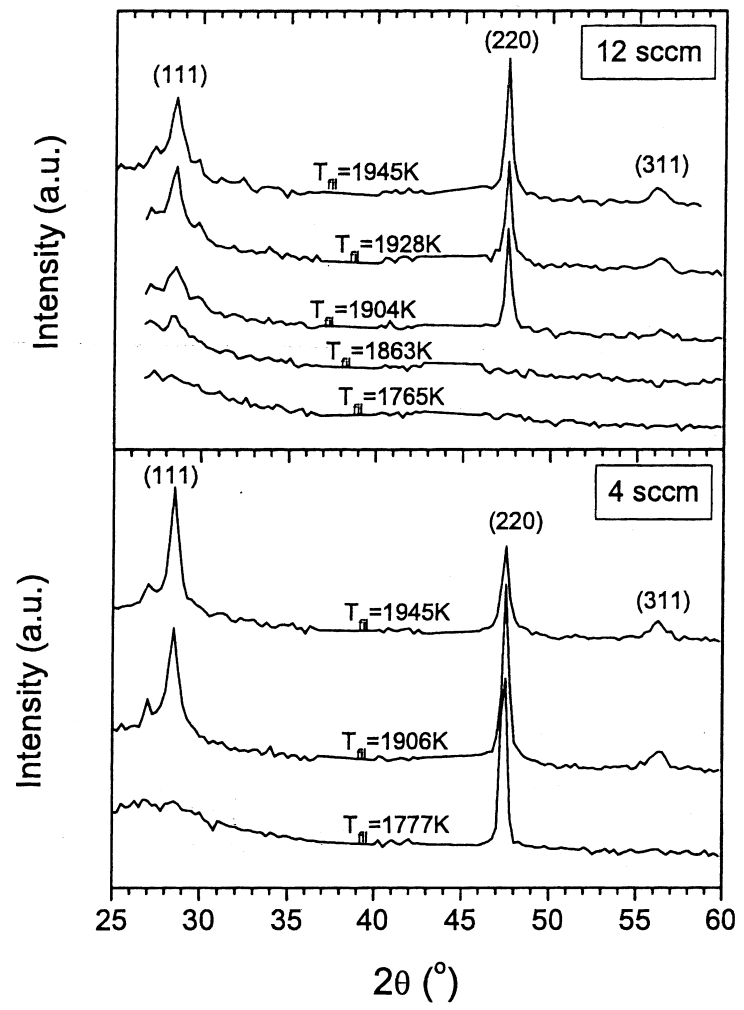

Fig. 3. XRD patterns for two series of samples deposited at a pressure of $0.1 \mathrm{mbar}$ and a substrate temperature of $\sim 500{ }^{\circ} \mathrm{C}$. In the top graph $12 \mathrm{sccm} \mathrm{SiH}_{4}$ and $150 \mathrm{sccm} \mathrm{H}_{2}$ were used, in the bottom graph 4 sccm $\mathrm{SiH}_{4}$ and $150 \mathrm{sccm} \mathrm{H}_{2}$.

crystalline silicon with a preferred $(220)$ orientation. Thin films with a dominant (2 20) orientation of the crystals are indeed obtained at tungsten filament temperatures at which silicide formation of the tungsten occurs and where we suspect that hardly any $\mathrm{H}_{2}$ dissociation occurs. Indeed, for Ta filaments, (2 20$)$-oriented material is reported [41] for filament temperatures below the threshold temperature for $\mathrm{H}_{2}$ dissociation [39]. Furthermore, the use of graphite filaments is reported to always lead to (2 20 )-oriented material [18], while it is known from the field of hot filament deposition of diamond that graphite does not efficiently dissociate $\mathrm{H}_{2}[42,43]$.

Further, the degree of depletion of the $\mathrm{SiH}_{4}$ plays a role in the structure of the deposited layers. Silane depletion conditions generally prevent the annihilation of atomic hydrogen [44] through the reaction $\mathrm{H}+$ $\mathrm{SiH}_{4} \rightarrow \mathrm{SiH}_{3}+\mathrm{H}_{2}$. In Figs. 3 and 4, using high $\mathrm{SiH}_{4}$ flow, we observe a transition from random microcrystalline to amorphous structure with decreasing filament temperature. Under depletion conditions (lower graph of Fig. 3) we observe a transition from multi-oriented microcrystalline to purely ( 220 )-oriented microcrystalline nature. It is thus concluded that random crystallinity is enhanced by high atomic $\mathrm{H}$ production. For obtaining

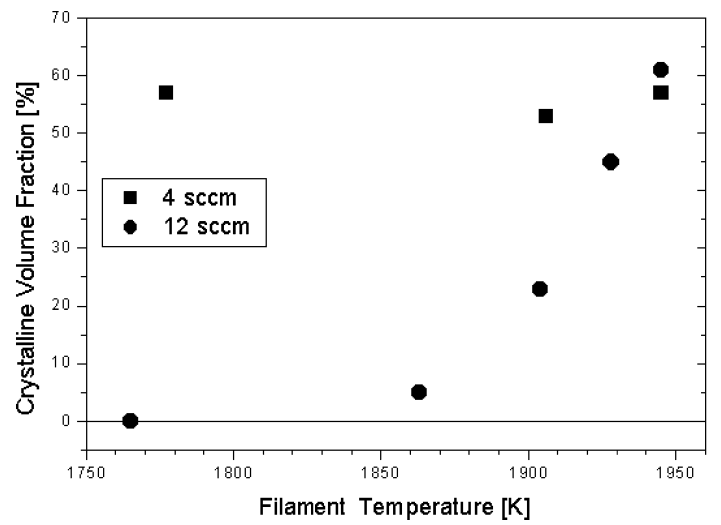

Fig. 4. The crystalline volume fraction vs. the filament temperature for the films deposited in these two series.

random crystallinity, $\mathrm{SiH}_{4}$ depletion is less important. On the other hand, primarily (2 20 )-oriented material results if both the primary atomic $\mathrm{H}$ production is limited and the silane is depleted.

The above poly-Si thin films are typically obtained at a deposition rate of $5 \AA / \mathrm{s}$. By increasing the catalytic surface area (doubling the number of filaments), while increasing the silane flow and keeping the $\mathrm{H}_{2}$ to $\mathrm{SiH}_{4}$ ratio constant, we have studied whether the deposition rate could be increased. It was found that with a high $\mathrm{SiH}_{4}$ gas flow rate of 30-35 sccm, a deposition rate as high as $7 \mathrm{~nm} / \mathrm{s}$ can be achieved for a material with a crystalline volume fraction $V_{\mathrm{f}} \sim 50 \%$. In Fig. 5, it can be seen that the depletion condition is maintained up to a $\mathrm{SiH}_{4}$ flow of $30 \mathrm{sccm}$.

However, these high deposition rate materials tend to be porous and take up oxygen after completion of the deposition and exposure to air. Nevertheless, it should be noted that for poly-Si at a deposition rate of $7 \mathrm{~nm} /$ $\mathrm{s}$, the photosensitivity of 55 is worth considering further development.

\section{2. $\mu \mathrm{c}$-Si:H 'from the poly-Si side'}

Microcrystalline silicon typically has a crystalline volume fraction ranging between 40 and $60 \%$. We have

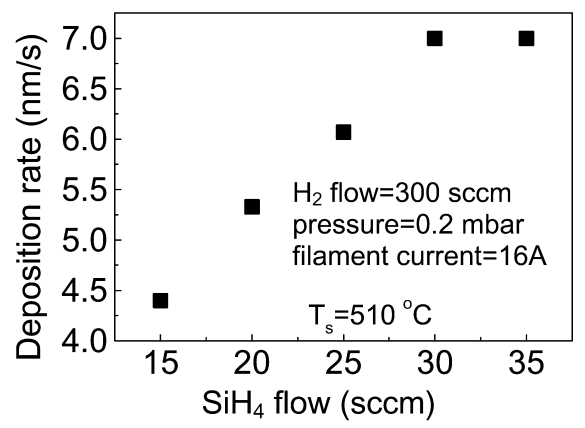

Fig. 5. Dependence of the deposition rate on the $\mathrm{SiH}_{4}$ flow. 
Table 1

Key deposition parameters and materials properties of the two intrinsic absorber layers

\begin{tabular}{lllll}
\hline Parameter & Poly-Si:H & $\begin{array}{l}\mu \mathrm{c}-\mathrm{Si}: \mathrm{H} \\
\text { (poly-approach) }\end{array}$ & $\begin{array}{l}\mu \mathrm{c}-\mathrm{Si}: \mathrm{H} \\
\text { (amorphous-approach) }\end{array}$ \\
\hline Wire material & $\mathrm{W}($ 2-wire) & $\mathrm{W}($ 4-wire) & Ta (2-wire) & Ta (2-wire) \\
$d_{\text {substrate-wire }}(\mathrm{mm})$ & 40 & 30 & 40 & 50 \\
$T_{\text {wire }}\left({ }^{\circ} \mathrm{C}\right)$ & 1800 & 1820 & 1750 & 1700 \\
$T_{\text {sub }}\left({ }^{\circ} \mathrm{C}\right)$ & 500 & 510 & 250 & 250 \\
Dilution ratio $\mathrm{H}_{2} / \mathrm{SiH}_{4}$ & 15 & 25 & 14 & 0 \\
Pressure $(\mu$ bar) & 100 & 200 & 50 & 20 \\
Deposition rate $(\AA / \mathrm{s})$ & 5 & 14 & 1.25 & 10 \\
Band gap $(\mathrm{eV})$ & 1.1 & 1.01 & & 1.8 \\
Activation energy $(\mathrm{eV})$ & 0.54 & 0.53 & $10^{3}$ & 0.8 \\
Photo-/dark conductivity ratio & $10^{2}$ & $2.4 \times 10^{2}$ & $10^{6}$ \\
\hline
\end{tabular}

taken two different approaches toward $\mu \mathrm{c}-\mathrm{Si}: \mathrm{H}$. The first is by starting from highly (2 20 )-oriented material with a crystalline volume fraction in excess of $90 \%$ and relaxing the crystallinity requirement. The second is by starting from amorphous silicon and gradually introducing small crystals. First, we discuss the approach from the poly-Si side. We kept the substrate temperature relatively high, at approximately $500{ }^{\circ} \mathrm{C}$ and we increased the deposition pressure as well as the hydrogen dilution ratio. In this way, the crystalline volume fraction went to $V_{\mathrm{f}}=60 \%$, while also ( 1111$)$-oriented nanocrystals $(\sim 27 \mathrm{~nm})$ where introduced in addition to the (2 20 ) -oriented nanocrystals $(\sim 26 \mathrm{~nm}$ ). The crystallite diameter thus came down from the $>100 \mathrm{~nm}$ to much smaller values. For a material comprising such small crystals, hydrogen passivation is very important. A higher hydrogen content was achieved by increasing the hydrogen dilution, bringing the bonded $\mathrm{H}$ content to $3.1 \%$ (up from $0.5 \%$ ). At the same time, much of the $\mathrm{H}$ ends up at crystal surfaces (as evidenced by the absorption at $2100 / \mathrm{cm}$ in IR absorption measurements). The photo- to dark conductivity ratio (photoresponse) went up from 100 to 240 , while the dark conductivity activation energy stayed at $0.53 \mathrm{eV}$.

Summarizing this approach, device-quality materials were obtained at a rate of $>1 \mathrm{~nm} / \mathrm{s}$ using a low silane gas flow of $6 \mathrm{sccm}$.

\section{3. $\mu c-S i: H$ 'from the $a-S i: H$ side'}

In this approach, we kept the substrate temperature at $250{ }^{\circ} \mathrm{C}$ (which had become the standard temperature for $\mathrm{a}-\mathrm{Si}: \mathrm{H}$ in our lab) and just slightly increased the pressure (to $50 \mu$ bar) while diluting the silane flow with $\mathrm{H}_{2}$. The dilution was varied from 0 to 33 . We used Ta wires for this approach, since Ta is the preferred filament for a-Si:H due to its longevity.

With the addition of $\mathrm{H}_{2}$ to the flow of $\mathrm{SiH}_{4}$, we observed a decrease in deposition rate (from 1 to 0.24 $\mathrm{nm} / \mathrm{s}$ ) while the crystalline fraction went up to $40-$ $50 \%$. The best material was found at a dilution ratio of
14 , just before the material tends to become porous. At higher dilution, the material becomes less compact and is prone to oxidation. The $\mathrm{H}$ concentration was approximately $6 \%$, and is present both in the $2000 / \mathrm{cm}$ mode and the $2100 / \mathrm{cm}$ mode. This material has (1 111$)$, (2 200$)$ and (3 111 )-oriented crystals, though the (2 200$)$ orientation is weakly dominant. The crystallite size remained very small, $10-20 \mathrm{~nm}$.

This deposition regime (low pressure, moderate dilution, low substrate temperature; in our case $50 \mu$ bar, flow ratio $14,250{ }^{\circ} \mathrm{C}$, respectively) is similar to that used by Klein et al. [45] (50 $\mu$ bar, flow ratio $\sim 13,185$ ${ }^{\circ} \mathrm{C}$ ), yielding 9.4\% $\mu \mathrm{c}-\mathrm{Si}: \mathrm{H}$ solar cells. High values for $V_{\text {oc }}$ are found, consistent with low values for the diode quality factor $n$ and the dark saturation current density, indicating excellent passivation of the grain boundaries. Researchers at NREL [46] have also recently identified this deposition regime to be beneficial for $\mu \mathrm{c}-\mathrm{Si}: \mathrm{H}$ materials. In their recent work, the process pressure has also been adjusted to 60 mTorr, the hydrogen to silane flow ratio was kept at 13 , and the substrate temperature has been decreased to $245{ }^{\circ} \mathrm{C}$. Thus, the conditions used worldwide for high quality microcrystalline silicon have been converging and are now strikingly similar.

As a result of systematic and careful optimization procedures we have chosen different substrate-to-wire distances, different wire temperatures and even different wire materials for poly-Si:H, $\mu \mathrm{c}-\mathrm{Si}: \mathrm{H}$ and a-Si:H deposition, respectively (Table 1 ).

\section{Thin film hot-wire deposited solar cells}

\subsection{Single junction cells}

Over the last 2 years, we have been concentrating on $\mathrm{n}-\mathrm{i}-\mathrm{p}$ type cells (single, tandem and triple cells) with microcrystalline silicon. All solar cells were made on plain SS substrates in the same configuration as our earlier HWCVD cell publications [47]. The cell structure is substrate type: SS/n-type $\mu \mathrm{c}-\mathrm{Si} /$ buffer/intrinsic $\mu \mathrm{c}$ $\mathrm{Si}: \mathrm{H} /$ buffer/p-type $\mu \mathrm{c}-\mathrm{Si} / \mathrm{ITO} / \mathrm{Au}$ (gridlines). Current 
Table 2

Solar cell parameters obtained for $n-i-p$ type cells on plain SS

\begin{tabular}{lclllll}
\hline Material & $\begin{array}{l}\text { Rate } \\
(\AA / \mathrm{s})\end{array}$ & $\begin{array}{l}\text { Thickness } \\
(\mu \mathrm{m})\end{array}$ & $\begin{array}{l}\eta \\
(\%)\end{array}$ & $\begin{array}{l}V_{\text {oc }} \\
(\mathrm{V})\end{array}$ & $\begin{array}{l}J_{\text {sc }} \\
\left(\mathrm{mA} / \mathrm{cm}^{2}\right)\end{array}$ & FF \\
\hline 'W'-poly-Si:H & 5.5 & 1.2 & 4.4 & 0.36 & 19.95 & 0.61 \\
'W'- $\mu \mathrm{c}-\mathrm{Si}: \mathrm{H}$ & 13 & 1.0 & 4.37 & 0.58 & 12.5 & 0.60 \\
'Ta'- $\mu \mathrm{c}-\mathrm{Si}: \mathrm{H}$ & 2.4 & 1.0 & 5.7 & 0.57 & 14.5 & 0.69 \\
'Ta'-a-Si:H & 10 & 0.4 & 7.2 & 0.89 & 11.2 & 0.72 \\
\hline
\end{tabular}

density-voltage $(J-V)$ measurements were taken under AM1.5 $100 \mathrm{~mW} / \mathrm{cm}^{2}$ white light from a dual beam solar simulator (WACOM, Japan). Note that at this stage we did not use a sophisticated back reflector to enhance the current density. All doped layers are made by PECVD at $13.56 \mathrm{MHz}$.

Using the intrinsic absorber materials of Table 1, we obtained results as summarized in Table 2.

It is worth noting that the two $\mu \mathrm{c}-\mathrm{Si}: \mathrm{H}$ cells with a moderate crystalline volume fraction have a very high $V_{\text {oc }}$ compared to most crystalline silicon thin film solar cells reported in Ref. [48]. For poly-Si cells without an intrinsic absorber layer, i.e. a n-/p-type solar cell, a large grain size (larger than the film thickness) is required for obtaining a high $V_{\mathrm{oc}}$. For the present cells, with crystal sizes smaller than $100 \mathrm{~nm}$, a high $V_{\mathrm{oc}}$ is possible due to the introduction of the intrinsic absorber layer, as in the present $n / i / p$ structures. The crystal orientation does not appear to be critical for obtaining a high $V_{\text {oc }}$, since the two $\mu \mathrm{c}-\mathrm{Si}: \mathrm{H}$ cells presented here have more randomly oriented crystals. It has been confirmed experimentally by Raman spectroscopy that these cells have microcrystalline nature throughout the entire layer, indicating that the high $V_{\text {oc }}$ cannot be due to an amorphous buffer-like interlayer in the front region of the cell. Two features of HWCVD, the lack of ion bombardment and the presence of a sufficient $\mathrm{H}$ flux to the growth zone, both of which presently being mimicked in PECVD by choosing the high pressure depletion regime [44], appear to be advantageous for the formation of high quality $\mu \mathrm{c}-\mathrm{Si}: \mathrm{H}$.

\subsection{Tandem and triple junction cells}

Recently, we presented [49] the first tandem solar cells made with two different hot-wire deposited components in the configuration $\mathrm{SS} / \mathrm{n}-\mathrm{i}-\mathrm{p} / \mathrm{n}-\mathrm{i}-\mathrm{p} / \mathrm{ITO}$. The efficiency of these cells was $8.1 \%$, while the total thickness was only $1.1 \mu \mathrm{m}$ and no enhanced back reflector was used. The absorber layer in the bottom cell was a poly-Si layer (previously called Poly2), made at $500{ }^{\circ} \mathrm{C}$ at a deposition rate in excess of $5 \AA / s$. As illustrated in the previous section, we have decreased the substrate temperature to $250{ }^{\circ} \mathrm{C}$, in order to produce a compact layer of microcrystalline silicon ( $\mu \mathrm{c}-\mathrm{Si}: \mathrm{H})$, combining a fairly high absorption coefficient at long- wavelength with improved values for the fill factor and $V_{\text {oc }}$.

Subsequently, this material was used in triple junction cell structures, comprising a bottom and middle cell of $\mu \mathrm{c}-\mathrm{Si}: \mathrm{H}$, and a top cell of a-Si:H. All intrinsic layers were made with the HWCVD method (Fig. 6).

First, we produced a cell, which had a bottom i-layer ( $\mu \mathrm{c}-\mathrm{Si}: \mathrm{H})$ with a thickness of $1320 \mathrm{~nm}$, the middle ilayer was $660 \mathrm{~nm}$, and the top i-layer (a-Si:H) was 165 $\mathrm{nm}$. The $J_{\text {sc }}$ was $7.45 \mathrm{~mA} / \mathrm{cm}^{2}$, suggesting that the currents were already quite well matched. It should be noted that there is no current enhancement due to a reflecting back contact and that the $\mu \mathrm{c}-\mathrm{Si}: \mathrm{H}$ layers (with a random crystal orientation) are not as textured as our Poly2 material which is exclusively (2 20 )-oriented. The high value for $J_{\text {sc }}$ suggests good long-wavelength response. The $V_{\text {oc }}$ is appropriately $1.725 \mathrm{~V}$, assuming $0.8 \mathrm{~V}$ for the top cell and values between 0.45 and 0.5 $\mathrm{V}$ for the bottom and middle cells. The fill factor is 0.66 .

The $\mathrm{p} / \mathrm{n}$ tunnel-recombination junction (TRJ) is of the structure p-type $\mu \mathrm{c}-\mathrm{Si}: \mathrm{H} / \mathrm{SiO}_{x} / \mathrm{n}$-type $\mu \mathrm{c}-\mathrm{Si}: \mathrm{H}$. As reported earlier [50], the $\mathrm{SiO}_{x}$ layer serves to enhance the 'good' recombination in the TRJ [51]. Recently, we have further optimized the current matching and the tunnel junctions. In particular, the thicknesses of the $\mathrm{n}^{+}$-type microcrystalline doped layers in the tunnel junctions were all reduced to $20 \mathrm{~nm}$, instead of the quite large thickness of $50 \mathrm{~nm}$ that was used in the previous triple cell. The thickness of the $\mathrm{n}^{+}$layer at the SS substrate was kept at $50 \mathrm{~nm}$, in order to avoid shunting due to the roughness of the SS. We also increased the crystallinity of the two narrow-gap i-layers and modified the thicknesses to compensate for the reduced parasitic

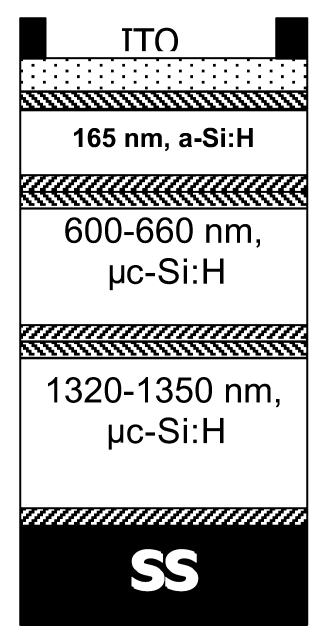

Fig. 6. Schematic cross-section of the a-Si:H/ $\mu \mathrm{c}-\mathrm{Si}: \mathrm{H} / \mu \mathrm{c}-\mathrm{Si}: \mathrm{H}$ triple junction cell on plain SS. All i-layers are deposited by HWCVD, all doped layers are $\mu c-S i: H$ PECVD layers. ITO is deposited by reactive thermal evaporation and grid contacts by vacuum evaporation. 


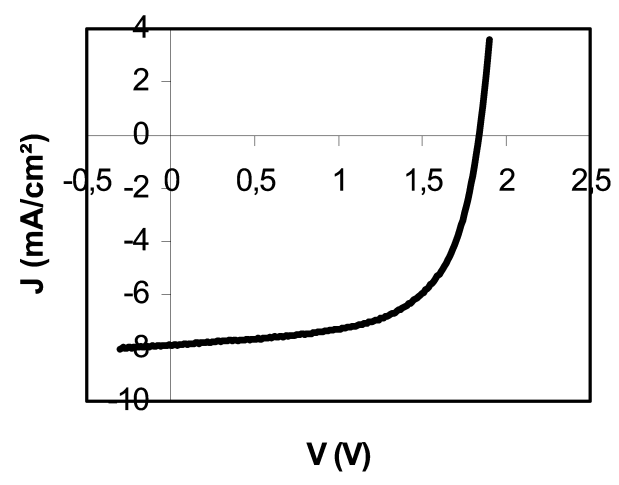

Fig. 7. $J-V$ characteristics of the a-Si:H/ $\mu c-\mathrm{Si}: \mathrm{H} / \mu \mathrm{c}-\mathrm{Si}: \mathrm{H}$ triple junction cell, with all i-layers deposited by HWCVD.

absorption in the tunnel junctions as well as for the increased crystallinity of the two bottom intrinsic layers. The present i-layer thicknesses are 1350, 600 and 165 $\mathrm{nm}$, from bottom to top, respectively. Due to these changes the $J_{\mathrm{sc}}$ for the best cell expectedly increased to $7.97 \mathrm{~mA} / \mathrm{cm}^{2}$. The $V_{\text {oc }}$ improved to $1.835 \mathrm{~V}$ but the FF decreased to 0.624 , probably because the top (amorphous) cell is no longer the limiting cell in this structure. In all, the efficiency improved to $9.1 \%$ (Fig. 7). Also, the distribution of the performance did improve. The average performance of the 10 best cells is $8.94 \%$, showing the excellent uniformity of performance. The yield (percentage of working cells) is $82 \%$. To inspect which component cell is limiting the yield, we measured the performance of the two lower cells as a tandem sample that was made during the same process. For these tandem cells (though, current mismatched) the yield was $97 \%$, indicating that the microcrystalline junctions are not limiting the yield.

Further work is necessary, among others on textured back reflectors. To conclude this section, as well as to show the potential of hot-wire deposited solar cells, Table 3 presents a collection of noteworthy cells that have been published thus far. It is by no means complete, but it serves to show various solar cell concepts that have great potential and have not been fully explored yet. The potential of these cells can be deduced by combining the strong points of various laboratories. For instance, the difference in short circuit current density, $J_{\mathrm{sc}}$, for cells with and without textured back reflector (or textured front electrode) can be as much as $6 \mathrm{~mA} /$ $\mathrm{cm}^{2}$, which translates into an increase in efficiency of single junctions cells from 7 to $10 \%$. The best microcrystalline silicon single junctions were reported by Klein et al. [45], using HWCVD intrinsic absorber material that is in some respects superior to PECVD materials. At Utrecht University, we found that single junction amorphous silicon cells can be surprisingly stable [32]. This is probably due to the protocrystalline nature of the silicon network, as the $\mathrm{H}$ flux to the growing film is much higher than in PECVD. From a comparison of the chemical reduction of thin coatings of metal oxides (such as $\mathrm{SnO}_{2}: \mathrm{F}$ ) in PECVD and $\mathrm{HWCVD}$, it has been estimated that atomic $\mathrm{H}$ is at least 5 times more abundant in the gas-phase [52]. It has also been deduced from secondary ion mass profiles (SIMS) that, under certain conditions, the large atomic hydrogen flux plays a role during growth in the subsurface region to a very large depth (up to $200 \mathrm{~nm}$ ) [53]. The potential of HWCVD cells could best be illustrated if the highly reflecting textured back reflector of NREL/USSC, the microcrystalline cell of IPV Jülich, and the TRJs and amorphous cell of Utrecht University were combined into one multijunction cell (Table 4).

\section{Large area capability}

In addition to the high deposition rate and high gas utilization, the elimination of expensive r.f. power supplies and matching boxes makes the HWCVD technique a low-cost production method for silicon thin films. For this technique to become more widely adopted, it is important to physically demonstrate the large area capabilities of the technique. At the recent International Conference on Cat-CVD (HWCVD) Process, held in Denver, Colorado, September 2002, an advanced 'showerhead' hot-wire assembly was presented [54]. Anelva has demonstrated a thickness uniformity of $\pm 7.5 \%$ over $96 \times 40 \mathrm{~cm}^{2}$ substrate area, and has thus overcome two main difficulties, the sagging of the filaments and the silicidation of the catalyst.

With this design, the two major issues of concern in HWCVD have been addressed. (1) Excessive silicide formation at the relatively cold ends of the wires, eventually leading to breakage of the wires. This is prevented by avoiding high concentrations of silane near the cold ends. The life of the wire can be further lengthened by preheating the wire for several minutes at $T_{\text {fil,treat }}=T_{\text {fil,process }}+500{ }^{\circ} \mathrm{C}$ with or without $\mathrm{H}_{2}$ gas. (2) Sagging of the wires by thermal expansion leading to an unwanted variation of the wire-to-substrate distance along the length of the wire. This is prevented by the use of a periodic arrangement of multiple short wires.

Another Japanese company, ULVAC Inc, is also actively developing large area systems. After the first demonstration in 2001 of uniform a-Si:H films over $92 \times 73 \mathrm{~cm}^{2}$, aiming at application in the LCD business (4th generation size substrates), they have recently presented a vertical system for $150 \mathrm{~cm}$ wide glass substrates (6th generation size). The filaments are arranged in a 'harp'-like fashion, by which the productivity is greatly enhanced since deposition can take place simultaneously on two substrates facing each other. In addition, the system footprint is greatly reduced. 
Table 3

A collection of noteworthy cells using HWCVD

\begin{tabular}{|c|c|c|c|c|}
\hline Laboratory & Structure of the cell & Remarks & $\eta$ init. (\%) & $\eta$ stab. $(\%)$ \\
\hline University of Kaiserslautern & glass/Asahi U/p-i(a-Si)-n/Ag & Superstrate amorphous single & 10.2 & 7.0 \\
\hline NREL/USSC & $\mathrm{SS} / \mathrm{Ag} / \mathrm{ZnO} / n-i(a-S i)-\mathrm{p} / \mathrm{ITO} /$ grid & Substrate amorphous single & 9.9 & 7.8 \\
\hline Utrecht University & plain SS/n-i(proto-Si)-p/ITO & Substrate amorphous single junction & 7.2 & $\Delta \eta \sim 10 \%$ \\
\hline Ecole polytechnique & glass/text.TCO/n-i( $\mu c-S i)-\mathrm{p} / \mathrm{Ag}$ & Superstrate inverted microcryst, single & 6.1 & \\
\hline FZ Jülich & glass/text.TCO/p-i( $\mu c-S i)-\mathrm{n} / \mathrm{ZnO} / \mathrm{Ag}$ & Superstrate microcryst, single & 9.4 & $\Delta \eta \sim 10 \%$ \\
\hline FZ Jülich & glass/text.TCO/p-i(a-Si)-n/p-i( $\mu c-S i)-\mathrm{n} / \mathrm{ZnO} / \mathrm{Ag}$ & Superstrate micromorph tandem & 10.9 & \\
\hline Utrecht University & plain SS $/ \mathrm{n}-i(\mu c-S i)-\mathrm{p} / \mathrm{n}-i(a-S i)-\mathrm{p} / \mathrm{ITO}$ & Substrate micromorph tandem & 8.1 & \\
\hline Utrecht University & plain SS/n-i(a-Si)-p/n-i(a-Si)-p/ITO & Substrate a-Si:H/a-Si:H tandem & 8.5 & \\
\hline Utrecht University & plain SS $/ \mathrm{n}-i(\mu c-S i)-\mathrm{p} / \mathrm{n}-i(\mu c-S i)-\mathrm{p} / \mathrm{n}-i(a-S i)-\mathrm{p} / \mathrm{ITO}$ & Substrate micro/micromorph triple junction & 9.1 & \\
\hline
\end{tabular}

The layers that are deposited by HWCVD are in italics. 
Table 4

Main solar cell characteristics of multijunction solar cells, made at Utrecht University, on plain SS

\begin{tabular}{|c|c|c|c|c|}
\hline Type of tandem cell & $V_{\mathrm{oc}}(\mathrm{V})$ & $J_{\mathrm{sc}}\left(\mathrm{mA} / \mathrm{cm}^{2}\right)$ & $\mathrm{FF}$ & $\eta(\%)$ \\
\hline Substrate micromorph tandem & 1.18 & 11.4 & 0.60 & 8.1 \\
\hline Substrate a-Si:H/a-Si:H tandem & 1.696 & 7.1 & 0.706 & 8.50 \\
\hline Substrate micro/micromorph triple junction & 1.835 & 7.97 & 0.634 & 9.1 \\
\hline
\end{tabular}

The intrinsic absorber layers are made using the HWCVD technique.

\section{Conclusion}

We have presented a review of the capabilities of HWCVD for the production of silicon thin-film based single junction and multijunction solar cells, based on demonstrated solar cell efficiencies in the laboratory as well as the first demonstrations of uniform large area deposition. The two most attractive features of HWCVD for implementation into the production environment are the high deposition rate and the highly efficient gas utilization.

The first HWCVD triple junction cells have been presented, combining two microcrystalline cells and one amorphous cell. The maximum temperature used for this entire triple junction cell is $250{ }^{\circ} \mathrm{C}$. The efficiency under AM1.5 is $9.1 \%$ and the cell performance over the substrate area is quite consistent. The total silicon thickness is approximately $2.2 \mu \mathrm{m}$ only. The deposition rates for $\mu \mathrm{c}-\mathrm{Si}: \mathrm{H}$ and a-Si:H are presently at 2.4 and 10 $\AA / s$, respectively. Further work on enhancement of the deposition rates is ongoing. Thus far, good $\mu \mathrm{c}-\mathrm{Si}: \mathrm{H}$ cells have been produced at $13 \AA / \mathrm{s}$ for the intrinsic microcrystalline layer. Two features of HWCVD, the lack of ion bombardment and the presence of a sufficient $\mathrm{H}$ flux to the growth zone, appear to be advantageous for the formation of high quality $\mu \mathrm{c}-\mathrm{Si}: \mathrm{H}$.

\section{Acknowledgments}

I would like to thank Karine van der Werf for deposition and optimization of all silicon layers and solar cells; Raul Jimenez Zambrano, Jochen Löffler, Hanno Goldbach and Gert Hartman for ITO and electrode development; Patrick van Veenendaal, Marieke van Veen, Paula Bronsveld, Aad Gordijn, Hongbo Li and Robert Stolk for their work on thin film development, Juriaan Adams, Arjen Bink, Jeroen Francke, Ruurd Lof, Gerard van der Mark and Marielle Rusche, for invaluable technical assistance, and Jatin Rath for the many discussions and for his contributions in various aspects of the progress, and all group members for providing the right atmosphere for advancing this field. This research has benefited from the financial support from NOVEM (Netherlands Agency for Energy and the Environment), EET (Economy, Ecology and Technology program of the Netherlands government) and the European Commission (FP5).

\section{References}

[1] H. Matsumura, Jap. J. Appl. Phys. 25 (1986) L949.

[2] A.H. Mahan, J. Carapella, B.P. Nelson, R.S. Crandall, I. Balberg, J. Appl. Phys. 69 (1991) 6728.

[3] R.E.I. Schropp, M.B. Schubert, J.P. Conde, A.H. Mahan, H. Matsumura (Eds.), Proceedings of the Second International Conference on Cat-CVD (Hot Wire CVD) Process, Denver, USA, September 10-13, 2002, Thin Solid Films 430 (2003).

[4] J.N. Smith, W.L. Fite, J. Chem. Phys. 37 (1962) 898.

[5] H.J. Wiesmann: US patent 4,237,150; December 2, 1980.

[6] H. Wiesmann, A.K. Ghosh, T. McMahon, M. Strongin, J. Appl. Phys. 50 (1979) 3752.

[7] H. Matsumura, H. Tachibana, Appl. Phys. Lett. 47 (1985) 833.

[8] J. Doyle, R. Robertson, G.H. Lin, M.Z. He, A. Gallagher, J. Appl. Phys. 64 (1988) 3215.

[9] H. Matsumura, Mat. Res. Soc. Symp. Proc. 118 (1988) 43.

[10] H. Matsumura, J. Appl. Phys. 65 (1989) 4396.

[11] A.H. Mahan, B.P. Nelson, S. Salamon, R.S. Crandall, J. NonCryst. Solids 137 and 138 (1991) 657.

[12] R.E.I. Schropp, M. Zeman, Amorphous and Microcrystalline Silicon Solar Cells: Modeling, Materials, and Device Technology, Kluwer Academic Publishers, Boston/Dordrecht/London, 1998, ISBN 0-7923-8317-6.

[13] R.E.I. Schropp, K.F. Feenstra, E.C. Molenbroek, H. Meiling, J.K. Rath, Philos. Mag. B 76 (1977) 309.

[14] B. Nelson, E. Iwaniczko, A.H. Mahan, Q. Wang, Y. Xu, R.S. Crandall, H.M. Branz, Thin Solid Films 395 (2001) 292.

[15] A.H. Mahan, Y. Xu, D.L. Williamson, W. Beyer, J.D. Perkins, M. Vanecek, L.M. Gedvilas, B.P. Nelson, J. Appl. Phys. 90 (2001) 5038.

[16] H.L. Duan, G.A. Zaharias, S.F. Bent, Mat. Res. Soc. Symp. Proc. 664 (2001) A3.1.1.

[17] P.A.T.T. van Veenendaal, C.M.H. van der Werf, J.K. Rath, R.E.I. Schropp, J. Non-Cryst. Solids 299-302 (2002) 1184.

[18] S. Morrison, A. Madan, Proceedings of the 17th European PVSEC (2001) 2951.

[19] K. Brühne, M.B. Schubert, C. Köhler, J.H. Werner, Thin Solid Films 395 (2001) 163.

[20] K. Inoue, S. Tange, K. Tonokura, M. Koshi, Thin Solid Films 395 (2001) 42.

[21] P.A.T.T. van Veenendaal, O.L.J. Gijzeman, J.K. Rath, R.E.I. Schropp, Thin Solid Films 395 (2001) 194.

[22] C.H.M. van der Werf, A.J. Hardeman, P.A.T.T. van Veenendaal, M.K. van Veen, J.K. Rath, R.E.I. Schropp, Thin Solid Films 427 (2003) 41.

[23] H. Matsumura, Jap. J. Appl. Phys. 37 (1998) 3175.

[24] N. Honda, A. Masuda, H. Matsumura, J. Non-Cryst. Solids 266-269 (2000) 100.

[25] H.L. Duan, G.A. Zaharias, S.F. Bent, Thin Solid Films 395 (2001) 36.

[26] E.C. Molenbroek, Ph.D. Thesis, University of Colorado (1995).

[27] S. Sakai, J. Deisz, M.S. Gordon, J. Phys. Chem. 93 (1989) 1888.

[28] A. Gallagher, Thin Solid Films 395 (2001) 25. 
[29] D.G. Goodwin, Mat. Res. Soc. Symp. Proc. 557 (1999) 79.

[30] K. Ishibashi, Thin Solid Films 395 (2001) 55.

[31] K.F. Feenstra, R.E.I. Schropp, W.F. van der Weg, J. Appl. Phys. 85 (1999) 6843.

[32] M.K. van Veen, Ph.D. Thesis, Utrecht University (2003).

[33] R.E.I. Schropp, Mat. Res. Soc. Symp. Proc. 762 (2003) A13.1.1.

[34] P.A.T.T. van Veenendaal, Ph.D. Thesis, Utrecht University (2002)..

[35] B. Stannowski, Ph.D. Thesis, Utrecht University (2002)..

[36] J.K. Rath, H. Meiling, R.E.I. Schropp, Jap. J. Appl. Phys. 36 (1997) 5436.

[37] R.E.I. Schropp, B. Stannowski, J.K. Rath, C.H.M. van der Werf, Y. Chen, S. Wagner, Mat. Res. Soc. Symp. Proc. 609 (2000) A31.3.

[38] R.E.I. Schropp, C.H.M. van der Werf, M.K. van Veen, P.A.T.T. van Veenendaal, R. Jimenez Zambrano, Z. Hartman, J. Löffler, J.K. Rath, Mat. Res. Soc. Symp. Proc. 664 (2001) A15.6.1.

[39] C.H.M. van der Werf, P.A.T.T. van Veenendaal, M.K. van Veen, A.J. Hardeman, M.Y.S. Rusche, J.K. Rath, R.E.I. Schropp, Thin Solid Films 420 (2003) 46.

[40] P.A.T.T. van Veenendaal, J.K. Rath, O.L.J. Gijzeman, R.E.I. Schropp, Polycrystalline semiconductors VI-materials, technologies, and large area electronics, in: O. Bonnaud, T. Mohammed-Brahim, H.P. Strunk, J.H. Werner (Eds.), Solid State Phenomena, vols. 80-81, Scitech Publication, 2001, p. 53.

[41] M. Fonrodana, D. Soler, J.M. Asensi, J. Bertomeu, J. Andreu, J. Non-Cryst. Solids 229-302 (2002) 14.
[42] M. Sommer, F.W. Smith, J. Mater. Res. 511 (1990) 2433.

[43] E. Zeiler, S. Schwarz, S.M. Rosiwal, R.F. Singer, Mater. Sci. Eng. A 335 (2002) 236.

[44] M. Kondo, M. Fukawa, L. Guo, A. Matsuda, J. Non-Cryst. Solids 266-269 (2000) 84.

[45] S. Klein, F. Finger, R. Carius, T. Dylla, B. Rech, M. Grimm, L. Houben, M. Stutzmann, Thin Solid Films 430 (1-2) (2000) 202.

[46] E. Iwaniczko, Y. Xu, B.P. Nelson, P. Stradins, A.H. Mahan, Mater. Res. Soc. Symp. Proc. 762 (2003) A7.8.

[47] R.E.I. Schropp, Thin Solid Films 403-404 (2002) 17-25.

[48] J.K. Rath, Solar Energy Mater. Solar Cells 76 (2003) 431.

[49] R.E.I. Schropp, C.H.M. van der Werf, M.K. van Veen, P.A.T.T. van Veenendaal, R. Jimenez Zambrano, Z. Hartman, J. Löffler, J.K. Rath, Mater. Res. Soc. Symp. Proc. 664 (2001) A15.6.1.

[50] J.K. Rath, F.A. Rubinelli, R.E.I. Schropp, J. Non-Cryst. Solids 227-230 (1998) 1202.

[51] F.A. Rubinelli, J.K. Rath, R.E.I. Schropp, J. Appl. Phys. 89 (2001) 4010

[52] J. Wallinga, W.M. Arnold Bik, A.M. Vredenberg, R.E.I. Schropp, W.F. van der Weg, J. Phys. Chem. B 102 (32) (1998) 6219-6224.

[53] K.F. Feenstra, P.F.A. Alkemade, E. Algra, R.E.I. Schropp, W.F. van der Weg, Prog. Photovolt. Res. Appl. 7 (1999) 341-351.

[54] K. Ishibashi, M. Karasawa, G. Xu, N. Yokokawa, M. Ikemoto, A. Masuda, H. Matsumura, Thin Solid Films 430 (1-2) (2003) 58. 